\title{
Humanistic Psychology Study of Abraham Maslow on the Main Character in Tiba Sebelum Berangkat Novel by Faisal Oddang
}

\author{
Sendika Lestari, Herman J Waluyo, Nugraheni E Wardani \\ Postgraduate of Sebelas Maret University, Indonesia \\ sendikalestari6451@gmail.com
}

\begin{abstract}
This article aims to analyze the main character in the novel Tiba Sebelum Berangkat by Faisal Oddang using the humanistic psychology approach of Abraham Maslow. The method used in this research was descriptive qualitative research method. The data source used was Tiba Sebelum Berangkat novel by Faisal Oddang. The data analysis technique in this study used the content analysis. The results of this study indicated that the main character in the novel Tiba Sebelum Berangkat by Faisal Oddang had and performed actions that can be analyzed by using Abraham Maslow's hierarchy of needs. This was shown by the content of the novel which presented about conflicts around human life; beliefs, religions, gender and love. Tiba Sebelum Berangkat novel tried to reflect on what might actually happen in people's real life in South Sulawesi. Based on the novel content, the main character built in the novel performed certain actions in obtaining multilevel needs that must be fulfilled as human beings. Tiba Sebelum Berangkat novel showed how humans obtained multilevel needs that must be fulfilled until human self-actualization was achieved.
\end{abstract}

Keywords : humanistic psychology; literature; novels; characters

\section{Introduction}

Novel as a literary work has an important role for readers. This is because a novel generally highlights about life and life issues. Life's problems are written as the basis of conflict in order to make what written by the author in the novel a livelier plot and characters. The root of the problem in the novel could be inspired by a real story or imaginary story of the essay of the author.

The character created by the author in the novel experiences various life conflicts. This makes the character also had a problem in fulfilling the needs. Fulfillment of needs is influenced by the behavior of the character to feel satisfied with the achievement of the needs obtained. Maslow (in Minderop, 2011: 280) suggests that human behavior is determined by the tendency of individuals to achieve goals so that the lives of these individuals are more happy and satisfying.

In the psychological studies, the need aspects must be given more attention. The need theory is a study carried and developed by Abraham Maslow. Maslow (in Hergenhahn, 2013: 839) provides an explanation of the hierarchy of human needs arranged based on their fulfillment potential. It is referred to as the need hierarchy because the fulfillment of these five needs is based on the top priority. The needs to be a prioritized for fulfillment.

Novel Tiba Sebelum Berangkat by Faisal Oddang reflects the reality of life of someone who experienced various events and improper treatment from his stepfather, Then received unpleasant treatment from Puang Matua Rusmi, was kidnapped and held as captive by a group on behalf of government defenders.

The novel tells how the inner experience of a character in living an unpleasant life as a minority. With all the events experienced, he still tried to prove that he was able to go through events after events with strength and patience. This situation does not make him discouraged and despair in achieving a better life with various efforts that he made based on his ability and effort to reach the stage of actualizing himself as a human being. 
Mapata character in this novel cannot be separated from various forms of need in living their lives. Mapata tries to fulfill all his basic needs until reaching the highest need level, that is self-actualization. Fulfilling needs is born as an impulse itself. In Mapata character his encouragement and motivation in fulfilling his needs. The courage in large part is an encouragement in the form of efforts to prove his love as a child to his parent until he is able to avenge his father's death. Other impetus that arises is able to make Mapata get to the stage of its actualization.

Research on the psychology of characters in novels has been carried out by many previous researchers, such as the research conducted by Nurhikma (2015) which examined "Aspek Psikologis Tokoh Utama Dalam Novel Sepatu Dahlan karya Khrisna Pabhicara" the main character was analyzed using humanistic psychological theory Abraham Maslow . The research showed the result that the main character of the novel being analyzed was described as a person who was more mature, strong, and independent in achieving the fulfillment of multilevel needs that he must obtain.

The other example was research that had been conducted by Septiarini and Handayani (2017) entitled "Kepribadian Tokoh Dalam Novel Mencari Perempuan Yang Hilang (Kajian Psikoanalisis Carl Gustav Jung)." The results of this study showed that the main characters in the novel had personality levels and each character had different personality types. These studies showed that the characters in the novel can be analyzed by using the existing psychological theories from psychologist. Like psychoanalysis of Carl Gustav Jung, humanistic psychology of Abraham Maslow, humanistic psychology of Carl Rogers, and others.

In contrast with the research mentioned previously, the purpose of this study was to describe the psychological aspects of the main character in Tiba Sebelum Berangkat novel by Faisal Oddang through humanistic psychological theory from Abraham Maslow.

\subsection{Novel Definition}

\section{Review of Literature}

A novel as one type of literatures is the result of an imagination of an author that was created to describe a situation and environment around it.

Nurgiyantoro (2002: 4) argues that the novel as a work of fiction offers a world. The world which is meant is that the world contains an ideal life model. The imaginative world is built through various intrinsic elements such as events, plots, characters and characterizations, backgrounds, points of view, etc. all of them are of course imaginative.

The above argument is in line with the opinion of Waluyo (2011: 5) who argues that the writing process of a novel is usually by the author by raising themes or stories related to the environment around the author. So it is not uncommon for readers to be carried away in the story, as if the readers themselves are experiencing the story.

Based on some of these meanings it can be concluded that the novel is an imaginative story that usually raises and tells the reality of human life in the form of complex problems that occur around the author.

\subsection{Literary Psychology}

Literary psychology is an approach of a science branch that is used to analyze and interpret the contents of a literary work related to aspects of the characters and authors of the literary work. Literary works are seen as psychological phenomena according to Wellek and 
Warren (1993: 90) when displaying psychological aspects through character if by chance the text is in the form of drama and prose.

This is in line with the opinion of Endraswara (2008: 16) which states that literary psychology is a study of literary works that reflect activities and psyche. The study was conducted to find out the psychological aspects of the characters and authors in literary works. This opinion is reinforced by a statement from Minderop (2011: 54) that the purpose of definitive psychology of literature is to understand the psychological aspects contained in a literary work through understanding the character created by the author.

From the above meanings, it can be concluded that literary psychology is a form of study that is used to examine and interpret the aspects that exist in a literary work in terms of the psychological character created by the author. This is done to make the reader understand about the psychology of the characters created by the author to make it easier for the reader to understand how the story and the complex conflicts that built by the author in his novel.

\subsection{Abraham Maslow's Humanistic Personality Psychology Theory}

Personality can be referred to as prioritizing the unconscious mind, which makes thinking structures colored by emotions. Murray (1967: 98) argues that personality is a function that organizes (regulates) or directs an individual. Its tasks include integrating conflicts and obstacles faced by individuals, satisfying individual needs, and drawing up plans to achieve future goals.

Personality according to psychology can also refer to patterns of behavioral characteristics and thought patterns that determine one's assessment of the environment. Personality is shaped by the potential possession from birth and modified by experiences gained, either unique experiences or cultural experiences, that influence someone as an individual (Minderop, 2011: 4).

Maslow as one of the pioneers of personality psychology thinks that humans are actually good creatures. However, humans experience various cultural conflicts and become victims of animal instincts. Some previous psychology studies emphasized that humans are negative, dark, sick, and animal instincts. Through this theory of humanistic personality, Maslow wants to show and reach the other side of humanity seen from the positive aspects that exist in that person.

Maslow sees humans from motivations that influence human behavior to achieve goals in life so that the lives they live in are happier and more satisfying. The motivations possessed by humans are the basis for the realization of human needs that must be fulfilled. The fulfillment these needs is arranged into a level of needs. It is called a hierarchy of needs because these needs are obtained based on their fulfillment priorities. The hierarchy of needs consists of five needs, namely; physiological needs, security, love and belonging, self-esteem and self-actualization. (Hergenhahn, 2013: 838)

Physiological needs are basic needs that must be met by humans. This need is is at the lowest level. This need is the most urgent need for fulfillment because it is related to human survival. Needs in the form of eating, drinking, breathing, rest, shelter, sexual needs, and the need for sleep. All these needs must be fulfilled so that the individual feels satisfied. If these needs are met, then the individual will continue to move towards fulfilling their next needs.

Maslow (in Hergenhahn, 2013: 839) describes that human as social being who has never been in a state of being fully satisfied. This makes people as individuals continue to move to meet the next needs that must be fulfilled. Individuals will feel dominated by subsequent needs continuously which position is higher in the needs hierarchy. 
Maslow (1987: 17) reveals that the thing that must be known is that not all individual needs must reach the stage of being fully satisfied and then the individual moves on to fulfill their next needs. Individuals can rise to a higher level of need and fulfill those needs if the individual feels that the needs can be met simultaneously.

For example, humans feel hungry and thirsty. The basic need that must be fulfilled here is how to satisfy that hunger and thirst by eating and drinking. However, it does not rule out the possibility that if the needs at a higher level when fulfilling these basic needs can also be fulfilled together. Because in life of these individuals should not only be dominated by thirst and hunger.

The next level of need is the need for security. This need is also referred to as psychological needs. Departing from physiological needs or physical needs that have been fulfilled, individuals also feel their psychological needs must be fulfilled. This need is a need that encourages individuals to get a sense of security both physically and psychologically.

In this need, individuals need a sense of tranquility, certainty, and orderliness of the circumstances around them. This need cannot be totally fulfilled because the essence of a person cannot be fully protected from dangers of other people's behavioral threats to their sense of security. However, this need is as much as possible to fulfill. As long as an individual feels he lives in an environment which is free of danger, fear, and chaos. (Maslow, in Goble, 1987: 126)

The need for love and belonging is a necessary after the need for security is sufficiently fulfilled. This need is present because, in essence, individuals in living their life need a good relationship with their family and environment. These individual needs for love and belonging are present as an impetus for individuals to have emotional ties to other individuals, both same-sex and the opposite sex, in the family environment and in the surrounding community groups.

Needs in the form of desire to have friends, the desire to have a partner and offspring, the need to be close to the family, and the need to love and being loved are the next level. Individuals have the right to love and be loved by other individuals. Being loved and accepted in the family and environment is the way to feel happy and satisfied. This makes individuals feel motivated to fulfill their needs at the higher level. However, if these needs are not met, individuals will feel lonely, alone, and empty.

After the need for love and belonging are fulfilled, the individual feels that he needs an award. This self-esteem needs include the recognition of others which results in feelings of achievement, acceptance and status, as well as self-esteem that result in self-confidence. Maslow (1987: 20) asserts that an award is born from the results of the individual's business. However, not all awards here must always be satisfied with something related to material, social status or achievement. It is believed that a person's self-actualization can never be measured by anything in this world.

\section{Research Method}

This research is conducted by using qualitative descriptive methods. This research method seeks to explain and describe the data analyzed by using the description in the form of words.

This is in line with the opinion of Moleong (2013: 16) that qualitative descriptive research is a study that produces descriptive data in the form of written or oral words about an individual, circumstances, and symptoms of certain groups that can be observed. 
In this study, researchers described qualitatively the results of the analysis carried out in the form of psychological aspects of the main character in Tiba Sebelum Berangkat novel by Faisal Oddang. The source of the data in this study is Tiba Sebelum Berangkat novel by Faisal Oddang, which was published by KPG (Popular Literature Gramedia) in 2018 which thickness was 216 pages. The data collection technique used by researchers was content analysis. The content analysis is a method that includes all analysis of the contents of the text, and content analysis is also used to describe a specific analytical approach.

The data analysis technique in this study uses the literary psychology approach based on the study of Abraham Maslow's needs theory to analyze the personality of the main character in the novel. The analysis was carried out by identifying data in the form of dialogues, sentences, and the main characters' words in Tiba Sebelum Berangkat novel by Faisal Oddang.

\section{Result and Discussion}

The aspects of humanistic psychology in the main character of Tiba Sebelum Berangkat novel by Faisal Oddang based on Abraham Maslow's Humanistic Psychology theory were presented as follows.

\subsection{Physiological Needs}

Physiological needs are also called needs at the most basic level that must be fulfilled by individuals. This need is a need related to the physical needs of humans, such as food, drink, shelter, and rest. In fulfilling this need, concerning the survival of the individual, this need is therefore urgent and must be fulfilled

The results of the analysis from the novel that have been read, several quotes and dialogues depicted psychological aspects in the form of physiological needs that must be fulfilled by the main character in the novel as in the following excerpts.

"At four in the morning, Mapata hasn't slept yet. The confinement room felt like a refrigerator and his whole body was numbed by stabbing cold into the bone. Mapata had been in the room for one month and had never changed clothes since the first day of his arrival." (TSB, 2018: 42)

"The most tormenting moment for Mapata was the morning. One week later, his sleep has never been much, much less sound. The bone was frozen. And why was it said to be torturous? Because at that time his stomach would ask for a bowel movement, while Mapata, with the remnants of his energy that was not much really lazy dragging the body into the corner of the room." (TSB, 2018: 53)

"Mapata's eyes began to fade, and her head felt heavy and enlarged. The stomach is like a laundry cloth that is squeezed before drying. As wrapped around something, he is starving." (TSB, 2018: 177)

Some of these quotes certainly showed that the main character should meet his physiological needs but because the main character was told to experience the situation and conditions as a detainee in a confinement room. It made him resisting his desire to fulfill all forms of basic needs like sleeping, clothing, shelter, which must be fulfilled for his survival. 
The excerpts also explained how the physical and psychological suffers experienced by the main character. The suffering was in the form of starvation, suffering in the form of cold because he has to sleep on the floor of the confinement room, suffering in the form of hunger, and suffering because his sleep time was disturbed and never restful again. Not fulfilling these basic needs certainly affected a person's behavior in carrying out his activities and making the individual vulnerable to do things that were deviant, even, it can harm him and others.

With such agony, the main character of Mapata in order to fulfill his needs after seven days of being kidnapped and was provided without food and drink for his survival, he was willing to eat his own feces for meal and drink the remaining rainwater in jerry cans. Basic needs that were urgent to fulfill tended to make individuals willing to do anything in order to obtain those needs. This included doing things that were not supposed to be done and considered as inappropriate things because they were dirty like eating their own feces. This can be proven in the quotations in Tiba Sebelum Berangkat novel as follows.

"It's just that, he is starving, not thirsty, anyway, there is still the remaining rain that he keeps in jerry cans. His mind was fixed on the bag of feces. He had no other choice when he shifted his body into a corner of the room and searched for bags with dry dung. In the beginning, dung was food as well, in the conditions it experienced, feces with spring rolls, for example, were no different." (TSB, 2018: 178)

The life lived and traveled by Mapata was indeed painful and apprehensive. After he was arrested and accused of involvement with the South Sulawesi sissy association organization that violated the Islamic Shari'a and was regarded as an organization against all forms of government activities at that time.

It was told a few moments before being kidnapped and confined, Mapata and his wife in fulfilling their physiological needs in the form of shelter, Mapata stole money belonging to Puang Matua Rusmi who had lied to him about being made a victim of bissu. The stolen money was used by Mapata to rent a kiosk and open a salon business to make money for providing their food and drink needs. It can also be proven in the following quotation.

"We moved away from the village, with supplies that we thought were more than enough. Upon arrival at Sengkang Central Market, we paid for a kiosk next to the market"

"Our money was running low, and I had no job at all until Batari asked me to open a salon after considering my ability of hair style as well as loving spells that were useful if I open a bridal makeup service." (TSB, 2018: 168-169)

The quote illustrated the fulfillment of the physiological needs of the main character and his wife. This certainly makes Mapata more focused on living the next life in order to realize the desires he wanted to achieve.

\subsection{Safety Needs}

The need for security is a need which must then be fulfilled. Prior to the confinement, Mapata had done everything he could fulfill all the basic needs. In fact, he was forced to steal money and gold belonging to Puang Matua Rusmi. This certainly made anxiety haunt Mapata. He imagined that bad things related to the security of himself and his wife would be threatened. This can be seen in the quote as follows. 
"Here we are, away from all possibilities that I cannot accept. I am not running away from a problem. I dare not guarantee that I can hold myself back if I still live in the same village as Puang." (TSB, 2018: 166)

"We walked through the forest then arrived on the highway to the city of Sengkang. Our security from Puang disorder, let it be my responsibility, Batari." (TSB, 2018: 174)

Security needs were present to be fulfilled after physiological needs had been met. Despite the physiological needs obtained by Mapata with encouragement, it created bad behavior, namely stealing. These things certainly made Mapata feel anxiety and concern about the security of himself and his wife. In such conditions, Mapata really needed the security in order to move to meet further needs.

\subsection{The Need for Love and Ownership}

The need for love and belonging was a necessity that encourages individuals to have friends, love, and affection towards family and others. As humans, this need was a natural desire to be fulfilled. Each individual must have a feeling of wanting to love, be loved, adore and be adored. This can be seen in the quotations of this novel as follows.

"Mapata, like other fathers and husbands, I clearly cannot stop troubling the two women he loves." (TSB, 2018: 43)

"Mapata hasn't slept yet. He remembered Walida, Has she dared to go to school? His tears dripped. He remembered Batari. How is she now? How do you convince Walida that she was okay?" (TSB, 2018: 45)

The quote above shows Mapata's form of love and affection as a husband and father. Even when he was held captive he thought and felt a deep desire for his child and wife. He was worried about the condition of his child and wife at home. These needs cannot be immediately met because Mapata's condition was still in captivity. The only way to fulfill this need, Mapata sent a letter to his wife and child through the jailer where he was held. Another thing he did was that every time before bed he remembered and thought of his child and wife.

From the quote, it appeared that indeed the need for love that Mapata possesses cannot be fulfilled in its entirety. However, this did not stop Mapata from making every effort to fulfill this need. This can be seen from the quote as follows.

"Yes, but this time I am serious, you have become my wife and you need to know, this is the only thing I can hold accountable as a husband besides making sure Walida is always fine. Do you hear that? "(TSB, 2018: 190)

The excerpt illustrates that even though the need for love cannot be fulfilled, Mapata strove to remain as a husband and father who is responsible for his family. The condition made him having the urge to continue to fulfill his next needs. 


\subsection{Self-Esteem Needs}

As someone who was depicted experiencing various sufferings from childhood, even when he was an adult. Mapata continued to live hard and patiently. He tried to do all the best he could do. Even though he was treated improperly by his stepfather, then received unpleasant treatment from Puang Matua Rusmi, was kidnapped and held captive by groups acting as government defenders. With all the events experienced, he still tried to prove that his existence must be considered by someone who had killed his father and he must also be valued as someone who did not harm the government as he had been accused.

"I'm revenge. I want to kill my father's assassin, so I decided to become a toboto for Puang Matua Rusmi. I know that being a toboto will also be sneered at, but the fire is already flaming, abstinence for half-hearted revenge. I learned all the knowledge of Puang to avenge. (TSB, 2018: 193)

"When contacted by an international institution, I immediately agreed to the conditions to create an organization that moves to assist small people and minorities. I formed Tidak Ada Yang Suci Di Bawah Matahari Ini (No Holy Beneath the Sun), then some friends joined in. We routinely conduct studies, investigations, and research related to government policies and other social problems.” (TSB, 2018: 206)

From the excerpt, it can be seen that in order to be able to meet further needs, Mapata sought to fulfill the need for self-esteem to continue to be able to obtain the need for its actualization. He showed that he as a child was there to avenge his father's death by willing to become a toboto for Puang Rusmi. Another thing that was pointed out by Mapata in fulfilling its self-esteem was that he formed an organization to voice minorities such as themselves as well as organizations that accompanied small people in South Sulawesi. He wanted to show that minorities and small people must also be considered by the government, because their existence actually never harmed the Indonesian government.

\subsection{Self Actualization Needs}

For all the bitter events experienced by Mapata, the last need that must be realized was the need for self-actualization. All the problems and conflicts that have passed through him made him want to be a better human being completely. He wanted to be a father and a husband who was responsible for his child and wife. He wanted to prove that he could recover from his psychological illness, same sex orientation. With all the abilities and efforts he had, he wanted to make up his mistakes for his wife and child by truly becoming a real man.

"Mapata who sits hindered by a table in front of the Batari just stares down. He never raised a gaze that might have been puffy. He met Batari, the only hope for continuing the future of his life. He wants to be a man fully responsible for Batari and Walida." (TSB, 2018: 208)

From the excerpt above it can be seen that Mapata met his wife in the hope that his wife was still waiting for his return. Mapata hoped to make up for all the wrongs and shortcomings as long as he was confined. He wanted to improve himself for his child; Walida. Mapata wanted to live his life with Batari better than before. 
However, the main character had a problem in fulfilling the actualization needs. The problem came from the fact that his wife married the guard who held him when he was captived by Ali Baba. This certainly made Mapata could not fulfill his actualization perfectly. The urge for his greatest desire and aspirations to be with his wife and child was hampered by the fact that his wife had married with other man.

\section{Conclusion}

Based on the results of the discussion stated above, conclusions could be drawn that Mapata character was described as strong, resilient, responsible, able to accept reality, love himself and his family. He did not give up easily for any problems and events that happened. In the most difficult conditions he tried to fulfill his basic needs as a human being. The experience of inappropriate and unpleasant actions he received from his childhood until he had a family did not make Mapata character stop fulfilling his actualization.

Although in fulfilling these needs, there were sometimes some needs that could not be fulfilled properly and in full, so that it was not uncommon for him to do deviant things. However, Mapata still tried to accept the reality and fulfilled its actualization properly, with efforts made he could change into a better human being. This was done not only by encouragement for the sake of the child and his wife, but also for himself.

\section{References}

Endraswara, S. (2008). Metodologi Penelitian Psikologi Sastra: Teori, Langkah, dan Penerapannya. Yogyakarta: FBS Universitas Negeri Yogyakarta.

Goble, F.. (1987). Mahzab Ketiga Psikologi Humansitik Abraham Maslow. Penj. Supratinya. Yogyakarta: Kanisius.

Maslow, A. H (1987). Motivation and Personality. New York: Harper \& Row

Matthew H. Oslon dan B.R Hergenhahn. (2013). Pengantar Teori-Teori Kepribadian. Terj. Yogyakarta: Pustaka Pelajar.

Moleong, L. (2013). Metodologi Penelitian Kualitatif. Bandung: PT. Remaja Rosdakarya.

Minderop, A. (2011). Psikologi Sastra: Karya Sastra, Metode, Teori dan Contoh (Terj). Jakarta: Yayasan Pustaka Obor Indonesia.

Murray, H. (1967). Exploration of Personality. New York: Oxford.

Nurgiyantoro. (2010). Teori Pengkajian Fiksi. Yogyakarta: Universitas Gadjah Mada Press.

Nurhikma. (2015). Aspek Psikologis Tokoh Utama Dalam Novel Sepatu Dahlan Karya

Khrisna Pabichara (Kajian Psikologi Humansitik Abraham Maslow). Jurnal Humanika 15 (3) pp 1-11

Oddang, Faisal. (2018). Tiba Sebelum Berangkat. Jakarta.PT. Gramedia

Septiarini, T. and Handayani, Renni. (2017). Kepribadian Tokoh Dalam Novel Mencari Perempuan Yang Hilang (Kajian Psikoanalisis Carl Gustav Jung. LINGUA 12 (2) pp 79-89

Waluyo, H. J. (2011). Pengkajian dan Apresiasi Prosa Fiksi. Surakarta: Sebelas Maret University Press.

Wellek, Rene dan Warren Austin. (1995). Teori Kesusastraan. Jakarta: Gramedia 